\title{
Does The XBRL Implementation and The Diversity of The Audit Committee Affect Quality of Financial Reports?
}

\author{
Nadya Rizki Amalia*, R. Nelly Nur Apandi, Agus Widarsono \\ Universitas Pendidikan Indonesia, Bandung, West Java, Indonesia
}

*Corresponding author:

E-mail: nadyarizki@upi.edu

\begin{abstract}
Problems in presenting non-uniform financial reports make it difficult for investors to process financial reports. So new technology is needed that can make investors and analysts easily process the information contained in financial reports. This research was conducted to obtain the relationship between the influence of XBRL on the quality of financial reports as moderated by the audit committee is IT knowledge. This research uses a quantitative approach with descriptive methods. Through descriptive research, the effect of using XBRL with the IT knowledge of the audit committee on the quality of financial reports is obtained. The research object in this study is a manufacturing company listed on the Indonesia Stock Exchange in 2016. The results of this study indicate that XBRL does not affect the quality of financial statements. Also, the audit committee's IT knowledge does not affect the quality of financial reports. XBRL also does not influence the quality of financial statements, moderated by the IT knowledge audit committee. In 2016, many companies used XBRL, and audit committees with educational backgrounds in the IT sector were not relevant.
\end{abstract}

Keywords: XBRL, quality of financial reports, audit committee, IT Knowledge

\section{Introduction}

The financial report is important for investors and analysts to assess the company's performance and condition. This is following the purpose of financial reporting - details on the Conceptual Framework IASB (2010) stating that quality financial information is useful for decision-making based on assessing the reporting entity's resources and condition. Financial reports are a medium that connects company owners (shareholders) and company management. Company owners tend to assess the company's performance during a certain period through released financial reports. A financial report is a form of accountability from management for its management during a certain period. One of the parameters for the success of management performance is based on the profit generated (Fitri \& Apandi, 2019). Also, the company should present the quality of the financial reports for reporting can be achieved. However, not all companies give better and structured financial statements, making it difficult for investors and analysts to assess their performance and condition. Investors require information in the form of financial statements that can be processed easily. At the same time, most companies use different formats in their financial reports, so it can be difficult for investors and analysts to process the data.

The financial statements should be quality and have quality information also. Properties qualitative of the financial statements, namely, relevant, understandable, have power test, neutral, timely, and can be compared and complete (Byard \& Cebenoyan, 2007). The quality of the financial statements better will be easier for investors and analysts in the data processing and assessing the company. A financial report is one of the main sources of making an investment decision. According To the Statement of Accounting Financial Standards (PSAK), the financial report represents the structure of an entity's financial position and financial performance. The financial report

\section{How to cite:}

Amalia, N. R., Apandi, R. N. N., \& Widarsono, A. (2021). Does The XBRL implementation and the diversity of the audit committee af-fect quality of financial reports?. $1^{\text {st }}$ ICEMAC 2020: International Conference on Economics, Management, and Accounting. NST Proceedings. pages 290-302. doi: 10.11594/ nstp.2021.1034 
plays an important role in the business world. It is being an important proof that could be hope for investors in the process of making a decision (Byard \& Cebenoyan, 2007). A financial report will better inform accurate, comprehensive, accurate, and trustworthy information so investors can easily determine the final investment decision (Jeffrey, 2016). Improvement of the Indonesia report's quality seen since 2015, where the year began effective implementation of a reporting system called XBRL.

The present financial statements' problems are not uniform, making it difficult for investors to process financial statements. The necessary technology can then make investors and analysts easily process the information in the financial statements. Answers to the problem are the XBRL (Extensible Business Reporting Language), a new technology that can increase financial statements' quality by providing comprehensive, actual, and efficient (Petersen \& Rajan, 2002). Gomaa et al. (2011) stated that the interaction between the data developed in XBRL provides convenience for users to browse data deep even up to the transaction phase (Cohen, 2009). XBRL is expected to facilitate the process of disclosing and disseminating information to users and regulators (Baldwin et al., 2006). Ease of access, information that is real-time, and the level of accuracy and independence of the financial report believed to the higher-rated increase the public and investors' confidence in the quality of the financial statements (Wanaputra \& Harahap, 2018). That the presence of a positive impact on the effectiveness of the XBRL in the trend of the financial reporting and capital markets (Wang et al., 2014).

XBRL brings a positive impact trend in financial reporting and capital markets. The presence of XBRL can facilitate the investor in processing the data in the financial statements. XBRL applied early can help the company reduce the input data are repeated, and errors in the input data can facilitate the financial statements' making (Zhou, 2019). Indonesia Stock Exchange (IDX) recently began developing XBRL in 2012. As a step in early development, BEI has completed a specific taxonomy for its financial statements in 2014, namely the Indonesia Stock Exchange (IDX) Taxonomy 2014, published on 30 April 2014. The taxonomy currently in force has been finalized through the process of public review implemented in March 2014. Taxonomy IDX acquires status "acknowledgment" from XBRL International. The taxonomy will be used to report financial statements by companies listed in the format of XBRL started in 2015 (Indonesia, 2020).

All the companies listed on the stock exchange without exception required to use reports based on XBRL in 2015. However, not all companies directly using XBRL in the financial statements of the company. Based on IDX data on July 26, 2017, the stock exchange company amounted to 554 of the issue. From the financial report 2015, published in the BEI, some companies are still some companies not using financial statements march XBRl. Companies that do not yet use XBRL in 2015 amounted to 48 and are spread in almost all major sectors in BEI.

Companies are still not using XBRL is still quite a lot. XBRL itself is expected to facilitate investors and analysts in the data processing in the financial statements. It is becoming an important proof that could be hope for investors in the process of making a decision (Byard \& Cebenoyan, 2007). According to Byard \& Cebenoyan (2007) said an increasing need for the market to improve the financial reports. This is because the quality of financial reporting would be relevant because of its performance in a time. The use of XBRL in reporting financial statements will improve operating efficiency, transparency, and decision-making (Heidari Gandoman \& Rostami, 2018). The quality of the financial report is increasing with the use of XBRL.

Previous research tests the influence of XBRL to improve the quality of financial reports in the company in Iran. Heidari Gandoman \& Rostami (2014) stated the presence of a direct relationship and significance between XBRL with reporting quality finance in Iran, on the other hand, also increases the classification transparency of financial funding and efficiency. Research done by (Prasetyo \& Apandi, 2019) states that XBRL affects the financial report's quality. XBRL will lower the possibility of doing policy the accrual of management to improve financial reports quality. XBRL 
is considered to be used as one way of accountability to the party shareholders because of the difference of interests between management and shareholders.

The difference in the management's interests and the shareholders required internal audit presence to meet government interests. The audit committee will assist the interests of the shareholders. The committee's role and functions in the audit are to assist the board in overseeing report finance (Wallace \& Zinkin, 2006). The overall process is more significant for shaping the company with good corporate governance (Wallace \& Zinkin, 2006). The audit committee's effectiveness in carrying out the functions to assist the board in maintaining the financial statements' quality will get better with the auditors who have a high quality.

Along with quality auditors, a high audit committee also should know about Information Technology (IT). The audit committee knows IT or has a background in IT. It will be able to implement reports financial are already using XBRL easily. With an audit committee background, the audit quality of financial statements can be better.

Rainsbury et al. (2009) stated found no evidence of the audit committee may improve the quality of financial reports. (Mutmainnah \& Wardhani, 2013) research, the audit committee has proven to improve the quality of financial reports based on two of the three measurements used: the persistence of earnings and profit predictability. These results indicate that more and more audit committee expertise will affect the report's quality better financially.

In this study, the authors see that not many do research linking directly between XBRL and the audit committee with the report's quality. Based on the description above, it raises some research questions here, namely (1) the Influence of XBRL on the quality of the financial statements; (2) the Influence of the audit committee on the quality of the financial statements; (3) the audit committee moderates the Influence of XBRL on the quality of financial reports. This research examines the relationship aspects of the system information and characteristics of information technology that have not been examined with the audit committee's educational background. See from the side of the XBRL (software) and the side of the brain is. The system information can be useful if elements in it are integrated. XBRL can improve the quality of the data generated; also, data can be reanalyzed.

\section{Literature Review Agency theory}

The theory of agency is the relationship and the contact that occurs between the principal and Agent. The agency theory assumes that each individual is motivated by their interests, which raises a conflict of interest between the principal and Agent (Jensen \& Meckling, 1976). The agency theory is the theory that explains the relationship agency as a contract between the principal and the Agent (Jensen \& Meckling, 1976). This relationship began to appear between the Agent and principal, and the Agent is management assigned to manage a company funded by investors or principal.

Both roles agreed to do an activity where the principal will employ an agent to manage the company or organization. The task of the Agent is to provide the information required by the principal. Also, the Agent must ensure that the company is already running well. Therefore, the need for an agent who has more knowledge of management provides that the principal's information is already according.

Of interest between the Agent and principal different. So, the Agent can behave in line with the principal. It is run through policy management. While the supervision of run by internal and external parties of the company against the Agent. Control of internal company in the form of an effective role of the council commissioner, audit committee, and internal auditors and auditors external. This research associate with the financial statements, namely the audit committee's supervision on the quality of financial statements using XBRL. In this case, Agent is a company where 
company publishes financial reports of good quality. So, the financial statements are of good quality then it is used a good information system also. The plan is used in the form of software (software) that is XBRL. The financial statements used by the principal. In this case, the principal is investors and data users of the financial statements.

\section{Quality of financial reports}

The financial statements must have good information that can be used to the maximum by prospective investors and other users. Assessment report finance, there are two major groups of attributes of the assessment, i.e., the attribute accounting-based and attribute-based market (Francis et al., 2004). The quality of financial reports based on accounting is the quality of accruals, persistence, predictability, and income smoothing. The quality attributes based on the market are the relevance of the value, timeliness, and conservatism.

According to Fanani (2005), the quality of financial reports has two points of view: the financial report's quality is associated with its overall performance described in the company's profit. This view declared earnings high-quality reflected on the profit that can be continuous (sustainable) for a while. The second view, namely, the quality of the financial statements relating to the capital market's performance, is realized in the form of rewards. Strong links between income the company in return show financial reporting high (Ayres, 1994).

Companies require information to perform their business activities. Expert accounting continues to develop financial accounting to fit the needs and can be more useful in decision making. Therefore made some classification on how the quality of the financial statements (Harahap, 2011).

Quality of financial reporting must be complete. According to Yadiati (2015) about a quality financial report is a financial report consisting of a balance sheet (balance sheet), describe the financial position of a business entity where it contains a balance between assets (assets), debt (liabilities), and capital (equity) pepper a specific period. Second, the income statement (income statement) is an overview of all the unitary business's revenues and expenses at a certain period. Third, the statement of equity changes is report additions to a unitary enterprise's capital consisting of comprehensive income, investment, and distribution from and to the owner. Fourth, the cash flow statement (cash flow) details all receipts and disbursements both from operating, investing, and financing activities at a certain period. Fifth, the notes to the financial statements contain information that is not expressed in the fourth report before. Such records will include the principle of the method and technique applied in the financial statements.

The financial statements' quality should have quality information also. Quality information will be disclosed if the company reports such information according to the rules of nature quality. The financial statements, i.e., relevant, understandable, have the power of the test, neutral, timely, and have the power of appeal and complete.

\section{Extensible Business Reporting Language (XBRL)}

Extensible Business Reporting Language (XBRL) an XML-based language that was created to be solving the problem of the inter-exchange of data in the world of business and automation processing the data directly (XBRL, 2013). Financial reporting format XBRL provides the language of financial reporting that can be authorized, where language or the term represents the financial statements' contents (XBRL, 2013). XBRL uses a format that allows the user to process the data up as deep as possible. The information is reported to be clearer, more independent, tested, and digital. Reporting digital can also help the user increase efficiency in conducting financial statement analysis (XBRL, 2013).

The Format of XBRL is the language in the HTML and XML that contains the taxonomy for the contents of the database report financial. Access to XBRL needed software to read it. Report XBRL can also be downloaded into various reporting formats depending on its software (Ghani et al., 
2014). The use of interactive data in XBRL is done by a process called "tagging," so the earlier data using a format such as Word, Excel, PDF, and so on can be processed into a form of XBRL that can be read by a computer (Gomaa et al., 2011).

The use of tagging the same as in the barcode of a product; however, its function is to bookmarks in the report (XBRL, 2013). The use of tagging in XBRL allows users to report confidently that the information can be used and analyzed accurately. Readers of financial statements can also explore and test the financial statements differently to see errors or error that happens and avoid them. Readers can also use the report is following the user according to their choices, such as the use of language, exchange rate, and the format of presentation of different. This is expected to convince the user that the data has been presented according to its understanding.

It reports comprehensive and tagging data that accurately allows the presentation, validation, publication, information exchange, consumption, and the analysis of the business's information to be used in all kinds. XBRL is useful as a bridge of information exchange between two or more information systems of the organization that are different.

The exchange of information often is an obstacle for some companies, ranging from the duration of the process analysis to the cost side, which is not cheap. Therefore, to save various costs that must be carried out in this process, the discourse to do the reporting online integrated directly with investors. Reporting finances online has advantages in cost-saving and more effective in delivering and various other conveniences that make this innovation a consideration for many the company to do so. In the process of implementation, there are several phases in the presentation of financial statements online. Step in financial reporting online is divided into three stages, namely, the phase before XBRL (pre-XBRL adoption phase), phase transition (transition phase), and phase the adoption of XBRL (pervasive adoption of XBRL phase) (Efrim Boritz \& No, 2009). In the financial statement phase, the first is the phase before XBRL (pre-XBRL adoption phase). This phase of financial reporting was presented in the form of paper-based or paper-based/physical. The financial statements of the be a source and media to be the source of the data should be translated into the format desired by the XBRL. Usually, the preferred format is HTML, PDF, DOC, and spreadsheet. Phase two is the phase transition (transition phase). In this phase, the company will first present its financial reports in paper-based or the desired format. The financial statements that have been made are paper-based then in translation to in the form of XBRL by using software that has been supporting this activity. Devices that support XBRL Tagging Software. The last phase is the adoption of XBRL (pervasive adoption of XBRl phase). In this phase, the information in the financial statements based on paper-based already translated in scripts XBRL. XBRL has been integrated into the general accounting information of the company. With the model/format of this output from the standard course report, the company/investor will easily sort fine details following the requirements it is desirable in the decision-making process.

In general, the benefits of XBRL, that is, increase the usefulness of the reporting system for electronic as it implements the standardized formats, so that generate information and data that is comparable and easy to analyze. Validation automatically to minimize the error input. Second, easy does publication of the report (including financial statements) because XBRL can be processed back into the desired format: PDF, HTML, Excel, TXT, etc. Third, improve ease of access to financial information, especially for international investors, because XBRL implements a standard identifying the information.

Overseas investors, it is possible to do their analysis independently and compare the decision business for investors. Fourth, the benefits are seen in automation, cost-saving, faster, more reliable, and more accurate data, analysis, improvement, and quality of better information and decision-making and accelerating business decision-making for investors. Fifth, the XBRL format useful for the development of Business Intelligence which will be used for the evaluation and monitoring of the listed company. 


\section{The effect of XBRL on the Quality of Financial Reports}

At this time, in the development era, all parties' information systems used in making the report finance should be easily understood. System information can be used to process the data and have useful information as well as quality. The quality of the report financial depending on the policy management in the financial statements reported. There is still management that uses discretionary accruals. Financial reports use discretionary accruals are high can make the quality of financial reports to be biased. The quality of the report a good financial should be free from the possibility of misstatements caused by management by using the policy accrual.

The quality of the financial statements is influenced by the accounting information system as well. A good accounting information system can generate a financial report useful and comparable. Information systems accounting can be easily understood by users and can reprocess for that requirement. The accounting information system is now widely used by many companies in other countries. It can be easily understood is the use of XBRL.

XBRL is software that can make it easier for users to create financial reports. By using XBRL, the quality of financial reports can be increased. Previous studies examine the effect of XBRL to improve the quality of financial reports on companies in Iran. (Heidari Gandoman \& Rostami, 2018) On the other hand, the existence of a direct relationship and significance between XBRL with the quality of financial reporting in Iran also improves the classification of transparency of financial funding and efficiency. Research conducted by (Prasetyo \& Apandi, 2019) stated that XBRL affects financial reporting quality. XBRL will lose the possibility of doing policy the accrual of so that management can improve financial reports' quality. XBRL considered it can be used as one-way accountability to the shareholders because of the difference in interests between management and shareholders.

H1: XBRL has a positive effect on the quality of financial reports

\section{Audit committee}

The audit committee is a committee formed and responsible to the Board of Commissioners in helping carry out the duties and functions of the Board of Commissioners (Badan Pengawas Pasar Modal dan Lembaga Keuangan, 2012). The committee audit has an important role in the process of the implementation of the layout of corporate governance better. The company's audit committee's main part is to help ensure the financial reporting company is of high quality. The audit committee and the board of commissioners a party to perform supervision and control for creating justice, transparency, accountability, and responsibility. The four factors that make the financial statements more quality (Sulistyanto, 2008).

The structure of the committee, the audit itself is under the board of commissioners. It is responsible for assisting the board of commissioners to ensure that the financial statements presented fairly following generally accepted accounting principles, the internal control structure of the company held by good, the implementation of internal and external audits conducted following the auditing standards that apply, and follow up audit findings implemented by management. The audit committee process is a task and chooses the external auditor, including the fee audit fee, which will be submitted to the board of commissioners. The audit committee also should pay attention to and assess the accounting policies and decisions related to accounting policies. The audit committee also examined the financial statements include the financial statements quarter, the annual report, the auditor's opinion, and management reports (Alijoyo \& Zaini, 2004).

The task of the audit committee is by the Decision of Chairman of Bapepam and LK No. KEP643/BL/2012 about The formation and Working Implementation Guidelines of Audit Committee stated that in operating its functions, the audit committee has the duties and responsibility, among others, (a) conduct a review of the information financial will be issued for Issuers or Public Companies to public and/or authorities such as financial reports, projections, and other reports related to financial information The issuer or Public Company; (b) Conduct a review of the observance of 
against the laws and regulations associated with the activities of the Issuer or Public Company; (c) Give an opinion independence in the event of a difference of opinion between management and the accountant on services rendered; (d) Provide recommendations to the board of commissioners regarding the appointment of accountant based on independency, scope of assignments, and fees; (e) Do a review of the implementation of inspection by internal auditors and oversee the performance of the no further by the board of directors on the findings of the auditor internal; (( $f$ ) Conduct a review of activity implementation risk management is carried out by the board of directors, if the Issuer or A Public company does not have the function of monitoring the risk under the the board of commissioners; (g) Examine complaints relating to the process accounting and finance for Issuers or Public Companies; (h) Reviewing and provide advice to the board of commissioners related to the presence of potential conflicts of interest the Issuer or Public Company; and (i) Maintain confidentiality of documents, data and information of the issuer or Of A Public Company.

It is associated with the responsibility and the audit committee's task closely with the financial reporting process. The committee of the audit must have the knowledge and financial expertise. In addition to having finance expertise, the audit committee should have other skills and the financial field. Expertise should also be there from the members of the audit committee is of the IT field. With the presence of members of the audit committee having a background in IT, it will be easy to follow the change of financial statements' format. Change the form of the financial information that is applied now is that XBRL. The audit committee has expertise in the IT field with easy-to-use software used by the company in processing financial reports with the format of XBRL. The audit committee also can easily understand how the use of the software.

\section{The effect of IT knowledge of the audit committee on the quality of financial reports}

The financial reports must have good information that can be used optimally by prospective investors and other users. The quality of the financial report-based accounting has the quality of accruals, persistency, predictability, and income smoothing. The quality of financial reports based on the market should have value relevance, accuracy time, and conservatism. A good financial report should be compared. The information system that is easily understood can also make financial statement information quality.

The audit committee is a committee assigned to help the board of commissioners oversee its financial activities. Internal control is performed by the company related to the operational and financial and engages directly in selecting external auditors used by the company in a certain period (Mutmainnah \& Wardhani, 2013). The audit committee is selected based on the background education that meets the company's requirements-associated with the audit committee's responsibility responsibilities and duties closely with the reporting process financial. The audit committee should have knowledge and expertise in finance. The audit committee's financial expertise should have other skills, such as the IT field. The more advanced the development of time, then it is necessary expertise in IT to follow the development of the information system provided globally.

The audit committee is under the commissioners' board and must be independent and not represent one of the company's interests. The audit committee also has an important role in strengthening the quality of financial reports. The audit committee will be supported by the existence that has the background the back of IT education. Previous research test of the audit committee on the quality of the financial statements. (Rainsbury et al., 2009) stated they find no evidence that the audit committee can improve the financial statements' quality. In the study of (Mutmainnah \& Wardhani, 2013), the audit committee is proven to increase the quality of financial reports based on two of the three measurements used the persistence of earnings and earnings predictability. This shows that more and more audit committee members can affect better financial reports' quality. 
H2: The audit committee has a positive effect on the quality of financial reports

\section{IT Knowledge of the audit committee moderates the influence of XBRL on the quality of finan- cial reports}

For companies that use the format of the financial statements using XBRL, the report finances' quality will increase. This is because XBRL affects the quality of financial reports. The financial statements' quality will be better if there is no audit committee with IT knowledge. The audit committee with IT knowledge is expected to understand XBRL well to make the quality of financial reports good.

H3: XBRL has a positive effect on the quality of financial reports reinforced with IT knowledge of the audit committee

\section{Material and Methods \\ Model research}

This study was conducted to obtain the relationship of the influence of XBRL on the quality of the financial statements moderated by the IT knowledge of the audit committee. This study uses a quantitative approach with the method descriptive. Through descriptive research obtained, the use of XBRL with IT knowledge of the audit committee on the quality of the financial statements.

Model regression to answer the first hypothesis in this study as the following:

$$
\begin{aligned}
& \text { Quality Financial Statements }= \\
& \qquad \alpha+\beta 1 \text { XBRL }+\varepsilon
\end{aligned}
$$

Model regression to answer the second hypothesis, as follows:

Quality Financial Statements $=$ $\alpha+\beta 2$ XBRL+ $+\varepsilon$

Model regression to answer the third hypothesis in this study, like the following:

Description:

$$
\begin{aligned}
& \text { Quality Financial Statements = } \\
& \qquad \alpha+\beta 3 \text { XBRL }+\varepsilon
\end{aligned}
$$

XBRL $=1$ If the company uses XBRL, 0 if not using XBRL

HOOK = 1 If the company is no members of the audit committee who has a background in IT, 0 if the company does not have an audit committee that knows IT

\section{Population, samples, and data analysis techniques}

The object of study in research is a Manufacturing Company listed on the Indonesia Stock Exchange in 2016. The population of this study consisted of 153 Manufacturing companies. The sampling technique of this research uses purposive sampling with conditions:

Table 1. Population and sample

\begin{tabular}{lll}
\hline No & Criteria & $\begin{array}{l}\text { The } \\
\text { of }\end{array}$ \\
\hline 1 & Company the manufacturing sector which listed on the stock exchange and \\
& presented the report financial year 2016 (in rupiah) & 84 \\
2 & The company that does not issue audited financial statements for complete & 22 \\
3 & The company that suffered losses in 2016 & 25 \\
4 & The company a report on the financial statements in Dollar & 22 \\
Total & 153 \\
\hline
\end{tabular}


Then the sample in this study consists of 84 companies. The type of data used in this study is secondary data obtained from the exchange's website. The effect of Indonesia, namely www.idx.co.id.

Methods of data analysis using the analysis of descriptive statistics and use inferential statistics using e-views. Testing requirements must meet the traditional test assumptions to generate a linear that focuses not on the minimum value (Best Linear Unlimited Estimator = BLUE) (Gujarati, 2009). After doing a Test of the BLUE, then testing the model and further hypothesis testing.

\section{Extensible business reporting language (XBRL)}

Variable reporting format XBRL measured using the variable dummy. If the company reported with the format of XBRL will be given a value of 1 . If not registered with the form of XBRL, will be given a value of 0 .

\section{Quality of the financial report (Y)}

The quality of financial reports in this research was measured using discretionary accruals. Discretionary accruals are calculated by subtracting the total accrual of the company's manufacturing-related in 2016 with non-discretionary accruals on manufacturing companies associated in the year 2016. The value obtained from non-discretionary accruals will show the quality of the financial statements of the company-owned of these. The smaller amount will show discretionary accruals a little so that financial reports can affect more quality than companies with a value nondiscretionary accruals great. This variable is measured by using the discretionary accrual model Modified Jones; the calculation is as follows:

a. Calculate the total accrual

Tait $=$ NIit - CFOit

Description:

TAit : Total accruals of a company I in year $t$

NIit: Net profit of company I in year $\mathrm{t}$

CFOit : Cash from operations of a company I in year $t$

b. Determining the rate of accrual of that normal (Non-Discretionary Accrual)

$\left.\mathrm{TA}_{\mathrm{it}} / \mathrm{A}_{\mathrm{it}-1}=\alpha_{1}\left(\frac{1}{A_{i t-1}}\right)+\beta 1\left(\frac{\Delta R E V_{i t}-\Delta R E C_{i t}}{A_{i t-1}}\right)+\beta 2\left(\frac{P P E_{i t}}{A_{i t-1}}\right)\right]$

Description:

TAit : Total accruals of a company I in year $t$

$\triangle$ REVit : Changes in the income of company I in year $t$

$\triangle$ RECit : Changes in accounts receivable of a company I in year $t$

PPEit : The fixed assets of a company I in year $t$

Ait-1 : Total assets of a company I in year t-1

Coefficient $\alpha 1, \beta 1$, and $\beta 2$ are regression coefficients obtained from the process of regression equation 2.

c. Calculate the level of accrual that is not normal (Discretionary Accrual). After the regression coefficients $\alpha 1, \beta 1$, and $\beta 2$ are obtained then these coefficients are inserted into equation 3 to get the value of the Discretionary Accrual (DAit) 


$$
\mathrm{DA}_{\mathrm{it}}=\mathrm{TA}_{\mathrm{it}} / \mathrm{A}_{\mathrm{it}-1}-\left[\alpha 1\left(\frac{1}{A_{i t-1}}\right)+\beta 1\left(\frac{\Delta R E V_{i t}-\Delta R E C_{i t}}{A_{i t-1}}\right)+\beta 2\left(\frac{P P E_{i t}}{A_{i t-1}}\right)\right]
$$

Description:

DAit : Discretionary Accrual the company I in the year of $t$

TAit : Total accruals of a company I in year $t$

$\triangle$ REVit : Changes in the income of company I in year $t$

$\triangle$ RECit : Changes in accounts receivable of a company I in year $t$

PPEit : The fixed assets of a company I in year $t$

Ait-1 : Total assets of a company I in year t-1

\section{The audit committee IT knowledge (Z) (Moderation)}

The variable of the audit committee is measured using the ordinal. How many companies' committee audits have a background in IT? If it does not have an audit committee background, IT will be given a value of 0 .

\section{Data analysis}

Data analysis techniques in this study use descriptive statistics and regression analysis panel data to analyze the variable XBRL (X) and the Audit Committee (Z) on the Quality of the Financial Reports (Non-Discretionary Accruals) (Y) using the help of software that is Microsoft Excel and Eviews. Hypothesis testing test statistic t essentially shows how far the influence of independent variables on the variable dependent. Testing is done by using a significant level of $0.05(\alpha=5 \%)$. If $\mathrm{t}<\mathrm{t}$ the table, Ho is accepted and Ha is rejected, if $\mathrm{t}$ count $>\mathrm{t}$ table, Ho is rejected and Ha is accepted (Ghozali, 2011). Statistical test $f$ the level of significance set at $5 \%$ or $0.05(\alpha=0.05)$ that is most likely a result of the conclusion having a $95 \%$ profitability or a $5 \%$ error tolerance. If $\mathrm{f}$ count $<\mathrm{f}$ the table, Ho is accepted and Ha is rejected, and if $\mathrm{f}$ count $>\mathrm{f}$ table, then Ho is rejected, and Ha is accepted (Ghozali, 2011).

\section{Results and Discussion Statistics descriptive}

This study aims to determine the effect of XBRL on the quality of financial reports, the influence of IT knowledge of the audit committee on the quality of the financial statements, and the impact of XBRL on the quality of financial reports are moderated with IT knowledge of the audit committee. Here are the results of statistics descriptive each variable:

Tabel 2. Statistics descriptive

\begin{tabular}{|c|c|c|c|c|c|}
\hline Name Variable & $\mathrm{N}$ & Mean & Std Dev & Min & Max \\
\hline XBRL & 84 & 0,37 & 0,48 & 0,00 & 1,00 \\
\hline $\begin{array}{l}\text { IT Knowledge of The Audit } \\
\text { Committee }\end{array}$ & 84 & 0,05 & 0,24 & 0,00 & 1,00 \\
\hline $\begin{array}{l}\text { Quality of The Financial Re- } \\
\text { ports }\end{array}$ & 84 & $-7,91$ & 24,76 & $-28,98$ & 30,01 \\
\hline
\end{tabular}

Based on the test descriptive statistics results in table 2, there are three variables research with a total sample of 84 companies. This study's dependent variable is that the quality of financial reports is measured using discretionary accrual models are modified jones. The value of the average (mean) across the sample of companies by -7,91. It shows that, on average, companies in the sample do discretionary accrual that indicates earnings management. The lowest value (minimum) $-28,98$. This shows the action companies do earnings management by lowering earnings. At 
the same time, the highest value (maximum) is 30,01 , which indicates earnings management's presence from the difference between the actual estimation of the accrual that should be obtained.

This research's independent variable is XBRL, measured with 1 if using XBRL and 0 if not using XBRL. The average cost of XBRL is 0.37 or $37 \%$. This means that 32 samples using XBRL. A moderating variable in this research is the IT knowledge of the audit committee. The average value (mean) of the IT knowledge committee audit is 0.05 . This means that only four companies have the audit committee holding IT in BEI in 2016.

Table 3. Test statistics

\begin{tabular}{llll}
\hline & Coefficient & the t-Statistic & Prob \\
\hline XBRL & 0.019102 & 0.047483 & 0.9622 \\
The committee Audit & 1.857415 & 1.489669 & 0.1402 \\
XBRL*Committee Audit & -0.186752 & -0.105159 & 0.9165 \\
\hline
\end{tabular}

\section{The effect of XBRL on the quality of financial reports}

Testing for the effect of XBRL on the quality of the financial report provides the results, not the effect. It can be seen from the probability values obtained 0,9622 . Based on the value of probability show greater than 0.05 , it can be concluded that hypothesis 1 is rejected. This study's results contrast with research (Heidari Gandoman \& Rostami, 2018) states the existence of a direct relationship and significance between XBRL with the quality of financial reports in Iran. Research done by (Prasetyo \& Apandi, 2019) says XBRL affects the financial report's quality. XBRL will lower the possibility of doing policy the accrual of management to improve financial reports quality.

This is because many companies that choose the audit committee do not see from the background back education. The research looked at the audit committee has a strong IT background, which can be understood and understand about XBRL. In Indonesia, users of XBRL are still a little because this study only took samples in the year 2016 alone, which is where that year is the year of the beginning of the adoption of XBRL.

\section{The effect of IT knowledge of the audit committee on the quality of financial reports}

Testing for the effect of IT knowledge of the audit committee on the quality of financial reports gives results no effect. It can be seen from the value of the probability obtained 0,1402 . Based on the value of the probability that is greater than 0.05 , it can be concluded that hypothesis 2 was rejected. This study's results contrast with research (Mutmainnah \& Wardhani, 2013) states of the audit committee has proven to improve the quality of financial reports based on two of the three measurements used, namely the persistence of earnings and earnings predictability. These results indicate that the more members of the audit committee who have the expertise will better impact the quality of the financial statements. This research is in line with (Rainsbury et al., 2009), which states did not find evidence that the audit can improve the quality of financial reports.

Background the education committee audit in the field of IT is not too relevant. The company took the committee audit, which has a background following the company or economics. The toplevel needs for the IT field are not significant because the quality of the financial reports is the management's ability.

\section{The effect of XBRL on the quality of the financial reports that moderated IT knowledge the audit committee}

This study uses a moderating variable that will control the independent variables to explain the dependent variable's existence. The influence of the will be shaped to strengthen or weaken the relationship (Belkaoui, 2006). In this research, the moderating variable of IT knowledge to see its influence on XBRL and the quality of the financial statements. 
Testing for the effect of XBRL on the quality of the financial reports that moderated IT knowledge, the audit committee gives the results of no effect. It can be judged from the probability value obtained 0,9165 . Based on probability values indicating greater than 0.05 , it is concluded that hypothesis 3 is rejected. This is because many of the company members who are members of the audit committee do not have a background in the back of IT - most of the members of the audit committee in the company background the field of economics. In addition to the background field, the economy has a background following the company's field.

\section{Conclusion}

Based on the research results and the discussion that has been conducted on the effect of XBRL on the quality of the financial reports that moderated the IT knowledge of the audit committee. Conclusion the results of testing the first hypothesis XBRL is no effect on the quality of financial reports. The results of testing the second hypothesis IT knowledge of the audit committee does not affect the quality of financial reports. The results of testing the third hypothesis influence XBRL on the quality of the financial statements that moderated IT knowledge the audit committee does not affect. In Indonesia, XBRL users are still small because it only took samples in 2016, which is the first year for XBRL implementations. The educational background of the audit committee in IT is not very relevant. The company takes on an audit committee with a background in the type of company or the economic field. The need from the top level for proficiency in IT is not significant because the quality of financial statements is management's ability.

This study uses three variables: XBRL, IT knowledge of the audit committee, and the quality of the financial report. XBRL can improve the quality of financial reports. For the quality of financial reports to improve properly. Suggestion for further research is adding to the variable others who influence XBRL and the report's quality and using a moderating variable that supports variable independent against the dependent variable. It can also be added that a manufacturing company can add a company listed on the stock exchange. Limitations of this study only researching manufacturing companies in the year 2016.

\section{Implications research}

This study can not provide empirical evidence that XBRL can improve the quality of financial reports. This can be caused due to knowledge of XBRL so that the necessary training to understand XBRL well. The necessity of training about XBRL can provide knowledge for the company and investors to understand XBRL.

\section{Limitations research}

This research's limitations are only applicable in 2016, where this is the first year of implementation of XBRL in Indonesia. This study did not examine after the year 2016, so we can not know with the existence of XBRL to be better whatnot. The factors that affect the adoption of XBRL are not only judging from the quality of the company. The company already applying XBRL in 2016 can not have the characteristics of how.

\section{Acknowledgment}

Thanks to the master of accounting science at the Indonesia Education University, who has encouraged research collaboration between students and lecturers.

\section{References}

Alijoyo, A., \& Zaini, S. (2004). Komisaris independen. Penggerak Praktik GCG di Perusahaan. PT. Indeks.

Ayres, F. L. (1994). Perceptions of earning quality: What managers need to know. Management Accounting (USA), 75 (9), 27.

Badan Pengawas Pasar Modal dan Lembaga Keuangan. (2012). Pembentukan dan pedoman pelaksanaan kerja komite audit. 2004. 
Baldwin, A. A., Brown, C. E., \& Trinkle, B. S. (2006). XBRL: An impacts framework and research challenge. American Accounting Association, 3(1), 97-116. https://doi.org/https://doi.org/10.2308/jeta.2006.3.1.97

Belkaoui, A. R. (2006). Accounting theory (2nd ed.). Salemba Empat.

Byard, D., \& Cebenoyan, F. (2007). Alternative evidence on financial analysts use of financial statement information. Review of Accounting and Finance, 6(4), 442-459.

Cohen, E. E. (2009). XBRL's global ledger framework: Exploring the standardised missing link to ERP integration. International Journal of Disclosure and Governance, 6(3), 188-206. https://doi.org/10.1057/jdg.2009.5

Efrim Boritz, J., \& No, W. G. (2009). Assurance on XBRL-related documents: The case of united technologies corporation. Journal of Information Systems, 23(2), 49-78. https://doi.org/10.2308/iis.2009.23.2.49

Fanani, M. (2005). Peranan komite audit dalam meningkatkan kinerja perusahaan. Jurnal Akuntansi Pemerintah, 1(1), 51-71.

Fitri, W. M., \& Apandi, R. N. N. (2019). Corporate action: Pengaruh stock repurchase dan kepemilikan keluarga terhadap audit fee. Organum: Jurnal Saintifik Manajemen Dan Akuntansi, 2(2), 104-116. https://doi.org/10.35138/organum.v2i2.54

Francis, J., LaFond, R., Olsson, P. M., \& Schipper, K. (2004). Costs of equity and earnings attributes. The Accounting Review, 79(4), 9671010.

Ghani, E. K., Said, J., \& Muhammad, K. (2014). Enhancing corporate governance via XBRL: Preparers' perception on compatibility expectation. Procedia - Social and Behavioral Sciences, 145, 308-315. https://doi.org/10.1016/j.sbspro.2014.06.039

Ghozali, I. (2011). Aplikasi analisis multivariate dengan program IBM SPSS 19. Badan Penerbit Universitas Diponegoro.

Gomaa, M. I., Markelevich, A., \& Shaw, L. (2011). Introducing XBRL through a financial statement analysis project. Journal of Accounting Education, 29(2-3), 153-173. https://doi.org/10.1016/i.jaccedu.2011.12.001

Gujarati. (2009). Basic econometrics. Mcgraw Hill International Edition.

Harahap, S. S. (2011). Teori akuntansi (Revisi 201). Rajagrafindo Persada.

Heidari Gandoman, S., \& Rostami, M. (2018). Investigating the Effect of Extensible Business Reporting Language (XBRL) on Quality Improvement of Financial Reporting in Iranian Corporations. SSRN Electronic Journal, 1-14. https://doi.org/10.2139/ssrn.3061847

Indonesia, B. E. (2020). XBRL. Indonesia Stock Exchange (IDX) Taxonomy 2020.

Jeffrey. C. (2016). Research on professional responsibility and ethics in accounting. Research on Professional Responsibility and Ethics in Accouinting, 20, i. https://doi.org/10.1108/s1574-0765 20140000018008

Jensen, M. C., \& Meckling, W. H. (1976). Theory of the firm : Managerial behavior , agency costs and ownership structure. 3, 305-360.

Mutmainnah, N., \& Wardhani, R. (2013). Analisis dampak kualitas komite audit terhadap kualitas laporan keuangan perusahaan dengan kualitas audit sebagai variabel moderasi. Jurnal Akuntansi Dan Keuangan Indonesia, 10(2), 147-170. https://doi.org/10.21002/jaki.2013.08

Petersen, M. A., \& Rajan, R. G. (2002). Does distance still matter? The information revolution. The Journal of Finance, LVII(6), 25332570.

Prasetyo, H., \& Apandi, N. N. (2019). Does Xbrl improve the quality of financial statements in the banking industry? The International Journal of Business Review (The Jobs Review), 2(2), 137-158. https://doi.org/10.17509/tir.v2i2.20499

Rainsbury, E. A., Bradbury, M., \& Cahan, S. F. (2009). The impact of audit committee quality on financial reporting quality and audit fees. Journal of Contemporary Accounting and Economics, 5(1), 20-33. https://doi.org/10.1016/i.jcae.2009.03.002

Sulistyanto, H. S. (2008). Manajemen laba teori dan model empiris. Grasindo.

Wallace, P., \& Zinkin, J. (2006). Mastering business in Asia: Corporate governance. Wiley India Pvt. Limited.

Wanaputra, F., \& Harahap, S. N. (2018). Analisis pengaruh XBRL terhadap kinerja perusahaan di India. Jurnal Ekonomi Dan Bisnis, 21(2), 219-240. https://doi.org/10.24914/jeb.v21i2.1686

Wang, T., Wen, C. Y., \& Seng, J. L. (2014). The association between the mandatory adoption of XBRL and the performance of listed stateowned enterprises and non-state-owned enterprises in China. Information and Management, 51(3), 336-346. https://doi.org/10.1016/j.im.2014.02.006

XBRL, I. (2013). An Introduction to XBRL.

Yadiati, W. (2015). Teori akuntansi suatu pengantar. Prenada Media Group.

Zhou, L. (2019). Research on internal audit model of banking construction based on XBRL Financial Report. 85(Icoeme), 271-277. https://doi.org/10.2991/icoeme-19.2019.51 